\title{
Probiotic Lactic Acid Bacteria: A Review
}

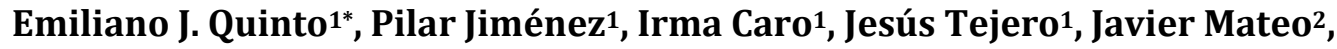 \\ Tomás Girbés ${ }^{1}$ \\ ${ }^{1}$ Department of Food Science and Nutrition, Faculty of Medicine and CINAD (Centro de Investigación en \\ Nutrición, Alimentación y Dietética; Edificio Lucia), University of Valladolid, Valladolid, Spain \\ ${ }^{2}$ Department of Food Hygiene and Technology, Faculty of Veterinary Medicine, University of León, León, Spain \\ Email: ${ }^{*}$ equinto@ped.uva.es
}

Received 11 June 2014; revised 18 July 2014; accepted 12 August 2014

Copyright @ 2014 by authors and Scientific Research Publishing Inc.

This work is licensed under the Creative Commons Attribution International License (CC BY). http://creativecommons.org/licenses/by/4.0/

(c) () 0 ir 0 pen Access

\begin{abstract}
Lactic acid bacteria (LAB) play a critical role in food production and health maintenance. There is an increasing interest in these species to reveal the many possible health benefits associated with them. The actions of LAB are species and strain specific, and depend on the amount of bacteria available in the gastrointestinal tract. Consumers are very concerned of chemical preservatives and processed foods. However, products with or processed with LAB are accepted as a natural way to preserve food and promote health. This paper aimed to review the recent data in regard to the role of probiotic LAB in the preservation of foods, in the immunomodulation in the gastrointestinal tract, and in its health benefits.
\end{abstract}

\section{Keywords}

\section{Lactic Acid Bacteria, Probiotic, Gastrointestinal Tract, Health}

\section{Introduction}

Lactic acid bacteria (LAB) are a group of Gram-positive, non-sporulating, anaerobic or facultative aerobic cocci or rods, which produce lactic acid as one of the main fermentation products of the metabolism of carbohydrates [1]. The monograph published by Orla-Jensen [2] is the base of the present classification of lactic acid bacteria (LAB) using the following criteria: cellular morphology, mode of glucose fermentation, range of growth temperature, and sugar utilization patterns. Four genera were recognized as LAB: Lactobacillus, Leuconostoc, Pediococcus, and Streptococcus. Molecular biological methods have increased the number of genera included in this group [3]. The current taxonomic classification includes the LAB group in the phylum Firmicutes, class Bacilli, and order Lactobacillales. The different families and genera can be search in the NCBI Taxonomy Browser

*Corresponding author. 
[4] or in the UniProt Taxonomy browser [5].

\section{Niche-Specific Adaptation: The Intestinal Environment}

The hypothetical first niche of the ancestral LAB is considered soil and plants and, subsequently, the gut of herbivorous animals [6]. The mammalian intestine is colonized by 100 trillions of microorganisms (called "microbiota”) that are essential for health [7] [8]. The transition from soil and plants to the animal gut has three areas of genomic adaptation [9]: resistance to host barriers, adhesion to intestinal cells, and fermentation of some substrates in the gut. The membrane lipid composition is affected by low pH and bile salts. Microarray analysis has shown the expression of a glycerophosphatase in Lactobacillus reuteri after an acid shock, and an increase in the sensitivity to acid in Lactobacillus acidophilus [10]. Extracelullar lipopolysaccharides (LPS) also play a role in the resistance, but it is unclear [6]. The adhesion of LAB to intestinal cells is associated with the peristaltic flow, a good adherence capacity and the presence of mucins to protect and lubricate the epithelial surfaces [11]. Resident intestinal bacteria are able to inhibit the adherence of pathogenic bacteria to intestinal epithelial cells as a result of their ability to increase the production of intestinal mucins [12]. Lactobacillus plantarum increases the levels of expression of the mRNA of some mucins, inhibiting the cell attachment of enteropathogenic Escherichia coli [13] [14]. LAB have access to simple sugars and complex carbohydrates, so bacteria with genes involved in its degradation are probably in better condition to multiply in the gut [6].

The resident gastrointestinal microbiota provide a microbial barrier against microbial pathogens [12]. Lactobacillus and Bifidobacterium spp. of human intestinal origin produce antimicrobial substances that are active in vitro and in vivo against enteropathogenic microorganisms involved in diarrhea [15]; both genera have the capacity for interfering with or block the pathogenic process of enteric bacterial pathogens [12]. Strains of Lactobacillus acidophilus, L. johnsonii, L. rhamnosus, L. casei, L. acidophilus, and L. rhamnosus interfere with a wide range of pathogens, such as enteropathogenic Escherichia coli, enterohemorrhagic E. coli, Listeria monocytogenes, Salmonella enterica serovar Typhimurium, and S. flexneri [16]-[22]. Blocking the process of pathogenicity of enteric pathogens is carried out without affecting their viability, such as the inhibition of Salmonella spp, S. flexneri, and L. monocytogenes by E. coli strain Nissle 1917 [23], and the blocking of E. coli LF82 adherent-invasion in the Crohn's disease [24].

\section{Biopreservation of Food}

Consumers are very concerned of chemical preservatives and processed foods, but they accept easily LAB as a natural way to preserve food and promote their health [25]. Bacteriocins are ribosomally synthesized small proteins produced by LAB that inhibit the growth of spoilage and pathogen bacteria in foods; moreover, bacteriocinogenic LAB are linked and are used as starter cultures in food processing [26]. Bacteriocins have been classified into four major groups [27]. Group I, also known as lantibiotics, has nisin as the first and best known bacteriocin. Group II is a large group of small heat-stable proteins subdivided into three groups [25]: i) subgroup IIa, bacteriocins active against Listeria monocytogenes, and pediocin PA-1, sakacins A and P, leucocin A, bavaricin $\mathrm{MN}$, and curvacin A are members of this group; ii) subgroup IIb require two different peptides for activity, and lactococcins $\mathrm{G}$ and $\mathrm{M}$, and lactacin $\mathrm{F}$ are members of it; and iii) subgroup IIc, such as lactacin B, require reduced cysteines for activity. Into group III are classified the larger heat-labile proteins, such as helveticins $\mathrm{J}$ and V, and lactacins A and B. Leuconocin S, lactocin 27, and pediocin SJ-1 have lipid or carbohydrate moieties and are classified into group I.V. Yang et al. [28] classified the gram-positive bacteriocins into three classes: Class I (modified peptides, lantibiotics), Class II (unmodified peptides, non-lanthionine), and Class III (large proteins, heat unstable). Cotter et al. [29] subdivided Class II into five sub-classes.

Only the bacteriocin nisin is commercially available for addition in pure form. It is added to milk, cheese, and dairy products, canned foods, mayonnaise, and baby foods [30]. Bacteriocinogenic cultures can also be added to the non-fermented foods or to fermented foods as starter cultures.

Due to the sensitivity of bacteriocins to some proteases, harmless bacteriocins are possibly digested [31] [32]. Thus, bacteriocins are considered as basically safe food additives after intake by the gastrointestinal system [28].

\section{Immunity Stimulation}

External microorganisms can penetrate the gut wall by translocation through the epithelial layer or through Peyer's patches. Indigenous intestinal bacteria including lactobacilli are able to cross the intestinal mucous layer 
and they can survive in the spleen or in other organs for many days where they stimulate phagocytic activity [33]. The thickness and physical state of the intestinal mucus layer [34] [35] and its response to orally consumed lactobacilli [36] [37] are important in the immune response.

Lactobacilli can elicit innate and adaptive immune response in the host via binding to specific receptors on immune cells and other tissues such as the intestinal epithelium [38]. Those receptors induce the production of cytokines, chemokines and other innate effectors: naïve $\mathrm{T}$ cells, regulatory $\mathrm{T}$ cells, and the activation of dendritic cells DC and macrophages [38]-[42]. Different strains and species of lactobacilli induce different effectors, which can modulate the immune response in different ways [38].

New approaches are been used to find immunomodulatory components of LAB. The comparative genomic analysis to identify loci linked to certain phenotypes has been done with Lactobacillus spp. [43]-[46]. However, a major gap in the knowledge about the mechanisms of immunomodulation by probiotic cells is their fate in vivo [38] [47]. Numerous probiotic studies with different strains of Lactobacillus have been performed in humans and murine models with negative/inconclusive or positive results. Positive results have been obtained treating acute infectious diarrhoea [48] or some allergic diseases such as the prevention of atopic eczema or dermatitis [49] [50]. These probiotics can increase the immunogenicity of orally administered vaccines such as rotavirus [51], polio [52], cholera [53] and influenza [54].

\section{Health Benefits}

The target of probiotic food products is to have up to $10^{7} \mathrm{CFU} / \mathrm{g}$ at the end of their shelf life [55]; but probiotic $\mathrm{LAB}$ must endure some stresses to ensure they reach the adequate numbers in the target location to elicit their effect. The human gastrointestinal tract contains up to $10^{13}-10^{14}$ cells [56]. It is a complex ecosystem combining the gastrointestinal epithelium, immune cells and resident microbiota [12] [57]. Simon and Gorbach [58] estimated a generation or doubling time between 1 and 4 per day.

The three major sections of the human gastrointestinal tract are the stomach, the small intestine, and the large intestine. Every section has its own distinct microbiota [56] [58]-[60]. The stomach is primarily inhabited by aerobic gram-positive microorganisms $\left(<10^{3} \mathrm{CFU} / \mathrm{g}\right)$. The small intestine is inhabited by the genera Lactobacillus, Bifidobacterium, Bacteroides, and Streptococcus $\left(10^{3}-10^{4} \mathrm{CFU} / \mathrm{g}\right)$. And the large intestine is populated by the genera Bacteroides, Fusobacterium, Lactobacillus, Bifidobacterium, and Eubacterium in large numbers $\left(10^{11}-10^{12} \mathrm{CFU} / \mathrm{g}\right)$.

There are many reports of the probiotic effect of LAB [61]. Some species involved are Lactobacillus acidophilus, L. casei, L. johnsonii, L. fermentum, L. rhamnosus, L. plantarum, L. reuteri, L. salivarius, L. paracasei, L. delbrueckii subsp. bulgaricus, Saccharomyces boulardii, Streptococcus thermophilus, Bifidobacterium lactis, B. longum, and B. breve. Probiotics presumably exert a dual effect, preventing/decreasing the intestinal colonization with pathogen microorganisms [62], or interacting with the gut-associated lymphoid tissue (GALT) to prevent inflammatory responses and promote a state of tolerance to themselves and possibly to foods [63].

The beneficial effects of probiotics are often disparate and strain-specific [64]. Some species conferred beneficial effects, such as the treatment of acute diarrhoea associated with rotavirus [51], ulcerative colitis [65] [66], Clostridium difficile-associated diarrhoea [67], and Helicobacter pylori infection [68] [69].

Some studies reported preventive effects, such as the prevention of antibiotic-associated diarrhoea in children [70], and improvement in lactose digestion [71]. Other effects are still under investigation [64]: liver disease, allergy, or AIDS.

Lucas and Cole [72] reported a decrease of necrotizing enterocolitis in preterm infants if Lactobacillus and Bifidobacterium colonize the intestine, or if breast milk rather than formula is used. Gewolb et al. [73] reported that premature infants delivered by caesarian section did not suffer the normal process by which LAB are ingested via vaginal birth and propagated by the mother's milk, allowing pathogens to establish within the premature intestine [74]. Hoyos [75] and Caplan and Jilling [76] reported that bifidobacteria reduced endotoxemia. The strongest evidence of a beneficial effect of probiotics has been reported for Lactobacillus rhamnosus GG and Bifidobacterium lactis BB-12 for prevention, and L. reuteri SD2222 for treatment [74]. Rohan and Wainwright [77] highlights the benefits of probiotic administration to babies $<1500 \mathrm{~g}$, in the reduction of the incidence and severity of necrotizing enterocolitis. There is no consistency in the type or combination of probiotics used. In different studies where only one probiotic strain was used there was not significant statistical change in the incidence of necrotizing enterocolitis; but when two or more probiotic strains were used in combination, a decrease in the incidence was observed [77]. 
Korterink et al. [78] performed a systematic meta-analysis for the use of probiotics for childhood functional gastrointestinal disorders (abdominal pain, vomiting and aerophagia), which cannot be explained in terms of structural or biochemical abnormalities. The use of Lactobacillus rhamnosus GG, L. reuteri DSM 17938 and $L$. reuteri VSL\#3 significantly increases treatment success in children with abdominal pain related with functional gastrointestinal disorders. In addition, L. rhamnosus GG and L. reuteri DSM 17938 significantly decrease the intensity of abdominal pain. Similarly, de Silva et al. [79] performed a systematic analysis of ways to prevent the development of food allergy in children and adults. Among several variables, probiotics did not seem to be protective in infants at high or normal risk. Redman et al. [80] carried out a study about the efficacy and safety of probiotic use in immunocompromised cancer patients, as case reports identified a Lactobacillus strain used in probiotic therapy to be involved with bacteremia [81] and sepsis [82]. The study demonstrated that there is currently insufficient evidence to claim that probiotics are effective and safe in people with cancer. In fact, metaanalyses found that probiotics significantly reduced the incidence of CTC grade $\geq 2$ diarrhoea (Common Terminology Criteria for Adverse Events, CTC, National Cancer Institute Common Toxicity Criteria, USA) [83], may reduce the incidence of CTC grade $\geq 3$ diarrhoea, may reduce the frequency of bowel movements, but most of the evidence is not clinically convincing, and they may be a rare cause of sepsis [80]. Ebel et al. [64] studied the impact of probiotics on risk factors for cardiovascular disease, such as medical disorders (obesity, diabetes, hypertension, and hypercholesterolemia) and metabolic disturbances (hyperhomocysteinemia and oxidative stress). Probiotics showed positive effects on the in vitro and in vivo studies considered for the study. These authors stated that those effects were most notably due to their anti-inflammatory properties or their enzymatic capacities. Moreover, no studies to date have directly addressed theimpact of probiotics on risk factors for cardiovascular diseases, which include aneurysm, angina, atherosclerosis, cerebrovascular accident, cerebrovascular disease, congestive heart failure, coronary artery disease, myocardial infarction, and peripheral vascular disease [64].

Finally, LAB are good candidates to develop novel oral vectors for mucosal delivery strategies, constituting attractive alternatives to attenuated pathogens. Bermúdez-Humarán et al. [84] studied the development of genetic tools for Lactococcus lactis for the heterologous expression of therapeutic proteins such as antigens, cytokines and enzymes. These authors obtained good results against human papillomavirus type 16 (HPV-16), to prevent a bovine b-lactoglobulin (BLG)-allergic reaction, and to regulate body weight and food consumption. The use of L. lactis to deliver DNA at the mucosal level has been also developed [84], modulating the host immune response.

\section{Enumeration of Probiotic Strains}

Standardized methods are available for a limited number of species in certain dairy products, such as publications from the International Organization of Standardization (ISO) regarding enumeration standards for Lactobacillus acidophilus (ISO 20128/IDF 192:2006) and Bifidobacterium (ISO 29981/IDF 220:2010) [85].

No single culture-based methodology is applicable to all probiotic microorganisms [85], because of the variability among species or strains. Moreover, the range of selective media available to identify and enumerate probiotic strains is relatively limited. There is not a single medium or technique applicable to strain isolation of all the microorganisms with probiotic interest.

In recent years new culture-independent methods havebeen used to accurately enumerate probiotic strains based on viability. These techniques either use dyes to differentiate live and dead cells, measure the cell membrane integrity, or characterize some aspect of metabolic activity (synthesis of nucleic acids, or respiration). Confocal scanning laser microscopy increases de sensitivity and enable the observation of subsurface structures of foods in situ [85]-[87]. The use of this technique in combination with the quantitative polymerase chain reaction (qPCR) has been used for the enumeration of probiotic strains in cheese [88] [89]. Ethidium monoazidePCR and propidium monoazide-PCR are emerging techniques that limit enumeration tolive cells and can also be referred to as viability-PCR (vPCR) [90] [91].

Cell sorting methods (Coulter counters and flow cytometry) were originally developed for counting red blood cells, but they have been upgraded and adapted to analyze much smaller cells such as bacteria [85]. Flow cytometry allows the study of a large number of cells at a time, recording, for each event (bacteria) several parameters. Different fluorescent probes can be applied to examine the physiological characteristics of probiotic living cells, such cell membrane integrity, intracellular enzyme activity, cytoplasmic $\mathrm{pH}$, and membrane potential [92]. Limitations and new challenges in probiotic enumeration and identification can be found in Davis [85]. 


\section{Antibiotic Resistance}

FAO/WHO [93] outlined the problem of antibiotic resistance genes in probiotic strains. The capacity of probiotics to transfer antibiotic resistance genes is one of the most important parameters for their selection [94], and their use should not the allowed [95].

When probiotics enter the gut, they interact with the native microbiota and gene transfer can occur, contributing to the transfer of antibiotic resistance genes to commensal or pathogen bacteria present in the gastrointestinal tract. Fukao and Yajima [96] reviewed the principal resistance genes in probiotic lactobacilli: tet, erm, or cat genes coding for tetracycline, erythromycin, or chloramphenicol resistances, respectively. D’Aimmo et al. [95] and Patel et al. [97] described other antibiotic resistance genes, such as str for streptomycin and vanA for vancomycin.

The identification of antibiotic resistances in probiotic strains could be done following phenotypic and genotypic methods: i) the determination of the minimum inhibitory concentration (MIC) of the most relevant antibiotics for each bacteria strain [98]; and ii) the use of PCR-based techniques and microarray analysis [99]-[101].

\section{Conclusions and Future Perspectives}

The expectations of probiotic bacteria have become the most demanding for any bacterial group. Probiotics have become a very important element to everyday health food products, and their global market is estimated above US\$28.8 billion by 2015 [59]. Consumers are very concerned of chemical preservatives and processed foods, even though it provides a grade of safety and food diversity never seen before. However, consumers accept easily LAB as a natural way to preserve food and promote their health. In the last decade the interest in bacteriocins produced by LAB has increased dramatically [26]. Many bacteriocins inhibit the growth of spoilage and pathogen bacteria in foods; moreover, bacteriocinogenic LAB are linked and are used as starter cultures in food processing. However, there are many different kinds of pathogens in nature, so the specific use of a particular bacteriocin cannot eliminate all bacterial pathogens. In recent years, the increased number of multi-drug resistant pathogens has become a serious problem. The development of a new generation of antimicrobial agents is a difficult task. Biotechnological methods are been applied to create new or multi-funtional bacteriocins, so they could be widely used in food, animal husbandry, and medicine.

Both traditional cell culture methods, as well as the alternative techniques (direct imaging and visual enumeration, nucleic acid-based enumeration methods, and flow cytometry and cell sorting), offer advantages and limitations for enumerating probiotic microorganisms [85]. The new methods and techniques show considerable promise for quantifying live microorganisms in different metabolic states. But the probiotic efficacy cannot be predicted solely on the basis of viable cells. Salminen et al. [102] reported that cell wall components from broth dead and living cells contributed to the probiotic efficacy.

Very few microorganisms have been subjected to thorough in vitro studies confirming their specific healthpromoting activity, and even fewer have been subsequently subjected to and passed the appropriate human trials [103]. Additionally, probiotics can be dangerous, as they have been linked to an increase in mortality rate if administered to severely immunocompromised patients [104]. Subsequent studies are needed to evaluate the health-promoting activity of probiotic bacteria.

\section{Acknowledgements}

This project was financially supported by the I + D + i Program, Junta de Castilla y León, Spain (SAN673/VA05/08, and SAN126/09).

\section{References}

[1] Hayek, S.A. and Ibrahim, S.A. (2013) Current Limitations and Challenges with Lactic Acid Bacteria: A Review. Food and Nutrition Sciences, 4, 73-87. http://dx.doi.org/10.4236/fns.2013.411A010

[2] Orla-Jensen, S. (1919) The Latic Acid Bacteria. Andr. Fred. Host and Son, Copenhagen.

[3] Von Wright, A. and Axelsson, L. (2012) Lactic Acid Bacteria: An Introduction. In: Lahtinen, S., Ouwehand, A.C., Salminen, S. and von Wright, A., Eds., Lactic Acid Bacteria: Microbiological and Functional Aspects, 4th Edition, Tayor \& Francis Group LLC, CRC Press, Boca Raton, 1-16.

[4] Anonymous (2014) NCBI Taxonomy Browser. 
http://www.ncbi.nlm.nih.gov/Taxonomy/Browser/wwwtax.cgi

[5] Anonymous (2014) UniProt Taxonomy browser. http://www.uniprot.org/taxonomy/186826

[6] Morelli, L., Calleagri, M.L., Vogensen, F.K. and von Wright, A. (2012) Genetics of Lactic Acid Bacteria. In: Lahtinen, S., Ouwehand, A.C., Salminen, S. and von Wright, A., Eds., Lactic Acid Bacteria: Microbiological and Functional Aspects, 4th Edition, Tayor \& Francis Group LLC, CRC Press, Boca Raton, 17-38.

[7] Hooper, L.V. and Macpherson, A.J. (2010) Immune Adaptations That Maintain Homeostasis with the Intestinal Microbiota. Nature Reviews Immunology, 10, 159-169. http://dx.doi.org/10.1038/nri2710

[8] Kamada, N., Seo, S.-U., Chen, G.Y. and Núñez, G. (2013) Role of the Gut Microbiota in Immunity and Inflammatory Disease. Nature Reviews Immunology, 13, 321-335. http://dx.doi.org/10.1038/nri3430

[9] Lebeer, S., Vanderleyden, J. and De Keersmaecker, S.C. (2008) Genes and Molecules of Lactobacilli Supporting Probiotic Action. Microbiology and Molecular Biology Reviews, 72, 728-764. http://dx.doi.org/10.1128/MMBR.00017-08

[10] Klaenhammer, T.R., Barrangou, R., Buck, B.L., Azcarate-Peril, M.A. and Altermann, E. (2005) Genomic Features of Lactic Acid Bacteria Effecting Bioprocessing and Health. FEMS Microbiology Reviews, 29, 393-409. http://dx.doi.org/10.1016/j.fmrre.2005.04.007

[11] Corfield, A.P., Myerscough, N., Longman, R., Sylvester, P., Arul, S. and Pignatelli, M. (2000) Mucins and Mucosal Protection in the Gastrointestinal Tract: New Prospects for Mucins in the Pathology of Gastrointestinal Disease. Gut, 47, 589-594. http://dx.doi.org/10.1136/gut.47.4.589

[12] Moal, V.L.-L. and Servin, A.L. (2006) The Front Line on Enteric Host Defence against Unwelcome Intrusion of Harmful Microorganisms: Mucins, Antimicrobial Peptides and Microbiota. Clinical Microbiology Reviews, 19, 315337. http://dx.doi.org/10.1128/CMR.19.2.315-337.2006

[13] Mack, D.R., Michail, S., Wei, S., McDougall, L. and Hollingsworth, M.A. (1999) Probiotics Inhibit Enteropathogenic E. coli Adherence in Vitro by Inducing Intestinal Mucin Gene Expression. American Journal of Physiology, 276, G941-G950.

[14] Mack, D.R., Ahrne, S., Hyde, L., Wei, S. and Hollingsworth, M.A. (2003) Extracellular MUC3 Mucin Secretion Follows Adherence of Lactobacillus Strains to Intestinal Epithelial Cells in Vitro. Gut, 52, 827-833. http://dx.doi.org/10.1136/gut.52.6.827

[15] Servin, A.L. (2004) Antagonistic Activities of Lactobacilli and Bifidobacteria against Microbial Pathogens. FEMS Microbiology Reviews, 28, 405-440. http://dx.doi.org/10.1016/j.femsre.2004.01.003

[16] Bernet-Camard, M.F., Lievin, V., Brassart, D., Neeser, J.R., Servin, A.L. and Hudault, S. (1997) The Human Lactobacillus acidophilus Strain LA1 Secretes a Nonbacteriocin Antibacterial Substance(s) Active in Vitro and in Vivo. Applied and Environmental Microbiology, 63, 2747-2753.

[17] Coconier, M.H., Bernet, M.F., Kerneis, S., Chauviere, G., Fourniat, J. and Sercin, A.L. (1993) Inhibition of Adhesion of Enteroinvasive Pathogens to Human Intestinal Caco-2 Cells by Lactobacillus acidophilus Strain LB Decreases Bacterial Invasion. FEMS Microbiology Letters, 110, 299-305. http://dx.doi.org/10.1111/j.1574-6968.1993.tb06339.x

[18] Coconnier, M.H., Lievin, V., Bernet-Camard, M.F., Hudault, S. and Servin, A.L. (1997) Antibacterial Effect of the Adhering Human Lactobacillus acidophilus Strain LB. Antimicrobial Agents and Chemotherapy, 41, 1046-1052.

[19] Coconnier, M.H., Lievin, V., Lorrot, M. and Servin, A.L. (2000) Antagonistic Activity of Lactobacillus acidophilus LB against Intracellular Salmonella enterica Serovar Typhimurium Infecting Human Enterocyte-Like Caco-2/TC-7 Cells. Applied and Environmental Microbiology, 66, 1152-1157. http://dx.doi.org/10.1128/AEM.66.3.1152-1157.2000

[20] Fayol-Messaoudi, D., Berger, C.N., Coconnier-Polter, M.-H., Moal, V.L.-L. and Servin, A.L. (2005) pH-, Lactic Acidand Non-Lactic Acid-Dependent Activities of Probiotic Lactobacilli against Salmonella enterica Serovar Typhimurium. Applied and Environmental Microbiology, 71, 6008-6013. http://dx.doi.org/10.1128/AEM.71.10.6008-6013.2005

[21] Gopal, P.K., Prasad, J., Smart, J. and Gill, H.S. (2001) In Vitro Adherence Properties of Lactobacillus rhamnosus DR20 and Bifidobacterium lactis DR10 Strains and Their Antagonistic Activity against an Enterotoxigenic Escherichia coli. International Journal of Food Microbiology, 67, 207-216. http://dx.doi.org/10.1016/S0168-1605(01)00440-8

[22] Hudault, S., Lievin, V., Bernet-Camard, M.F. and Servin, A.L. (1997) Antagonistic Activity Exerted in Vitro and in Vivo by Lactobacillus casei (Strain GG) against Salmonella typhimurium C5 Infection. Applied and Environmental Microbiology, 63, 513-518.

[23] Altenhoefer, A., Oswald, S., Sonnenborn, U., Enders, C., Schulze, J., Hacker, J. and Oelschlaeger, T.A. (2004) The Probiotic Escherichia coli Strain Nissle 1917 Interferes with Invasion of Human Intestinal Epithelial Cells by Different Enteroinvasive Bacterial Pathogens. FEMS Immunology and Medical Microbiology, 40, 223-229. http://dx.doi.org/10.1016/S0928-8244(03)00368-7

[24] Boudeau, J., Glasser, A.L., Julien, S., Colombel, J.F. and Darfeuille-Michaud, A. (2003) Inhibitory Effect of Probiotic 
Escherichia coli Strain Nissle 1917 on Adhesion to and Invasion of Intestinal Epithelial Cells by Adherentinvasive E. coli Strains Isolated from Patients with Crohn's Disease. Alimentary Pharmacology \& Therapeutics, 18, 45-56. http://dx.doi.org/10.1046/j.1365-2036.2003.01638.x

[25] Montville, T.J. and Winkowski, K. (1997) Biologically Based Preservation Systems and Probiotic Bacteria. In: Doyle, M.P., Beuchat, L.R. and Montville, T.J., Eds., Food Microbiology: Fundamentals and Frontiers, ASM, Washington DC.

[26] Hoover, G. and Steenson, L.R. (1993) Bacteriocins of Lactic Acid Bacteria. Academic Press Inc., New York.

[27] Klaenhammer, T.R. (1993) Genetics of Bacteriocins Produced by Lactic Acid Bacteria. FEMS Microbiology Reviews, 12, 39-86. http://dx.doi.org/10.1111/j.1574-6976.1993.tb00012.x

[28] Yang, S.-C., Lin, C.-H., Sung, C.T. and Fang, J.-Y. (2014) Antibacterial Activities of Bacteriocins: Application in Foods and Pharmaceuticals. Frontiers in Microbiology, 5, 1-10. http://dx.doi.org/10.3389/fmicb.2014.00241

[29] Cotter, P.D., Ross, R.P. and Hill, C. (2013) Bacteriocins-A Viable Alternative to Antibiotics? Nature Reviews Microbiology, 11, 95-105. http://dx.doi.org/10.1038/nrmicro2937

[30] Hurst, A. (1981) Nisin. Advances in Applied Microbiology, 27, 85-123. http://dx.doi.org/10.1016/S0065-2164(08)70342-3

[31] Cleveland, J., Montville, T.J., Nes, I.F. and Chikindas, M.L. (2001) Bacteriocins: Safe, Natural Antimicrobials for Food Preservation. International Journal of Food Microbiology, 71, 1-20. http://dx.doi.org/10.1016/S0168-1605(01)00560-8

[32] Bernbom, N., Licht, T.R., Brogren, C.H., Jelle, B., Johansen, A.H., Badiola, I., Vogensen, F.K. and Norrung, B. (2006) Effects of Lactococcus lactis on Composition of Intestinal Microbiota: Role of Nisin. Applied and Environmental Microbiology, 72, 239-244. http://dx.doi.org/10.1128/AEM.72.1.239-244.2006

[33] Deitch, E., Specian, E., Steffen, E. and Berg, R. (1990) Translocation of Lactobacillus murinus from the Gastrointestinal Tract. Current Microbiology, 20, 177-184. http://dx.doi.org/10.1007/BF02091994

[34] Atuma, C., Strugala, V., Allen, A. and Holm, L. (2001) The Adherent Gastrointestinal Mucus Gel Layer: Thickness and Physical State in Vivo. American Journal Physiology Gastrointestinal Liver Physiology, 280, G922-G929.

[35] Johansson, M.E., Phillipson, M., Petersson, J., Velcich, A., Holm, L. and Hansson, G.C. (2008) The Inner of the Two Muc2 Mucin-Dependent Mucus Layers in Colon Is Devoid of Bacteria. Proceedings of the National Academy of Sciences of the United States of America, 105, 15064-15069. http://dx.doi.org/10.1073/pnas.0803124105

[36] Troost, F.J., van Baarlen, P., Lindsey, P., Kodde, A., de Vos, W.M., Kleerebezem, M. and Brummer, R.J. (2008) Identification of the Transcriptional Response of Human Intestinal Mucosa to Lactobacillus plantarum WCFS1 in Vivo. BMC Genomics, 9, 374. http://dx.doi.org/10.1186/1471-2164-9-374

[37] van Baarlen, P., Troost, F.J., van Hemert, S., van der Meer, C., de Vos, W.M., de Groot, P.J., Hooiveld, G.J., Brummer, R.J. and Kleerebezem, M. (2009) Differential NF-KappaB Pathways Induction by Lactobacillus plantarum in the Duodenum of Healthy Humans Correlating with Immune Tolerance. Proceedings of the National Academy of Sciences of the United States of America, 106, 2371-2376. http://dx.doi.org/10.1073/pnas.0809919106

[38] Wells, J.M. (2011) Immunomodulatory Mechanisms of Lactobacilli. Microbial Cell Factories, 10, S17. http://dx.doi.org/10.1186/1475-2859-10-S1-S17

[39] Coombes, J.L. and Maloy, K.J. (2007) Control of Intestinal Homeostasis by Regulatory T Cells and Dendritic Cells. Seminars in Immunology, 19, 116-126. http://dx.doi.org/10.1016/j.smim.2007.01.001

[40] Bogunovic, M., Ginhoux, F., Helft, J., Shang, L., Hashimoto, D., Greter, M., Liu, K., Jakubzick, C., Ingersoll, M.A., Leboeuf, M., Stanley, E.R., Nussenzweig, M., Lira, S.A., Randolph, G.J., Merad, M. (2009) Origin of the Lamina Propria Dendritic Cell Network. Immunity, 31, 513-525. http://dx.doi.org/10.1016/j.immuni.2009.08.010

[41] Varol, C., Vallon-Eberhard, A., Elinav, E., Aychek, T., Shapira, Y., Luche, H., Fehling, H.J., Hardt, W.D., Shakhar, G. and Jung, S. (2009) Intestinal Lamina Propria Dendritic Cell Subsets Have Different Origin and Functions. Immunity, 31, 502-512. http://dx.doi.org/10.1016/j.immuni.2009.06.025

[42] Kwon, H.K., Lee, C.G., So, J.S., Chae, C.S., Hwang, J.S., Sahoo, A., Nam, J.H., Rhee, J.H., Hwang, K.C. and Im, S.H. (2010) Generation of Regulatory Dendritic Cells and CD4 ${ }^{+}$Foxp $^{+}$T Cells by Probiotics Administration Suppresses Immune Disorders. Proceedings of the National Academy of Sciences of the United States of America, 107, 2159-2164. http://dx.doi.org/10.1073/pnas.0904055107

[43] Pretzer, G., Snel, J., Molenaar, D., Wiersma, A., Bron, P.A., Lambert, J., de Vos, W.M., van der Meer, R., Smits, M.A. and Kleerebezem, M. (2005) Biodiversity-Based Identification and Functional Characterization of the Mannose-Specific Adhesin of Lactobacillus plantarum. Journal of Bacteriology, 187, 6128-6136. http://dx.doi.org/10.1128/JB.187.17.6128-6136.2005

[44] Denou, E., Pridmore, R.D., Berger, B., Panoff, J.M., Arigoni, F. and Brussow, H. (2008) Identification of Genes Asso- 
ciated with the Long-Gut-Persistence Phenotype of the Probiotic Lactobacillus johnsonii Strain NCC533 Using a Combination of Genomics and Transcriptome Analysis. Journal of Bacteriology, 190, 3161-3168. http://dx.doi.org/10.1128/JB.01637-07

[45] Meijerink, M., van Hemert, S., Taverne, N., Wels, M., de Vos, P., Bron, P.A., Savelkoul, H.F., van Bilsen, J., Kleerebezem, M. and Wells, J.M. (2010) Identification of Genetic Loci in Lactobacillus plantarum That Modulate the Immune Response of Dendritic Cells Using Comparative Genome Hybridization. PLoS ONE, 5, e10632. http://dx.doi.org/10.1371/journal.pone.0010632

[46] Lakhdari, O., Cultrone, A., Tap, J., Gloux, K., Bernard, F., Ehrlich, S.D., Lefevre, F., Dore, J. and Blottiere, H.M. (2010) Functional Metagenomics: A High Throughput Screening Method to Decipher Microbiota-Driven NF-kappaB Modulation in the Human Gut. PLoS ONE, 5, e13092. http://dx.doi.org/10.1371/journal.pone.0013092

[47] Meijerink, M. and Wells, J.M. (2010) Probiotic Modulation of Dendritic Cells and T Cell Responses in the Intestine. Beneficial Microbes, 1, 317-216. http://dx.doi.org/10.3920/BM2010.0029

[48] Sazawal, S., Hiremath, G., Dhingra, U., Malik, P., Deb, S. and Black, R.E. (2006) Efficacy of Probiotics in Prevention of Acute Diarrhoea: A Meta-Analysis of Masked, Randomised, Placebo-Controlled Trials. Lancet Infectious Diseases, 6, 374-382. http://dx.doi.org/10.1016/S1473-3099(06)70495-9

[49] Kalliomaki, M., Salminen, S., Arvilommi, H., Kero, P., Koskinen, P. and Isolauri, E. (2001) Probiotics in Primary Prevention of Atopic Disease: A Randomised Placebo-Controlled Trial. The Lancet, 357, 1076-1079. http://dx.doi.org/10.1016/S0140-6736(00)04259-8

[50] Kalliomaki, M., Salminen, S., Poussa, T., Arvilommi, H. and Isolauri, E. (2003) Probiotics and Prevention of Atopic Disease: 4-Year Follow-Up of a Randomised Placebo-Controlled Trial. The Lancet, 361, 1869-1871. http://dx.doi.org/10.1016/S0140-6736(03)13490-3

[51] Isolauri, E., Joensuu, J., Suomalainen, H., Luomala, M. and Vesikari, T. (1995) Improved Immunogenicity of Oral D x RRV Reassortant Rotavirus Vaccine by Lactobacillus casei GG. Vaccine, 13, 310-312. http://dx.doi.org/10.1016/0264-410X(95)93319-5

[52] de Vrese, M., Rautenberg, P., Laue, C., Koopmans, M., Herremans, T. and Schrezenmeir, J. (2005) Probiotic Bacteria Stimulate Virus-Specific Neutralizing Antibodies Following a Booster Polio Vaccination. European Journal of Nutrition, 44, 406-413. http://dx.doi.org/10.1007/s00394-004-0541-8

[53] Paineau, D., Carcano, D., Leyer, G., Darquy, S., Alyanakian, M.A., Simoneau, G., Bergmann, J.F., Brassart, D., Bornet, F. and Ouwehand, A.C. (2008) Effects of Seven Potential Probiotic Strains on Specific Immune Responses in Healthy Adults: A Double-Blind, Randomized, Controlled Trial. FEMS Immunology and Medical Microbiology, 53, 107-113. http://dx.doi.org/10.1111/j.1574-695X.2008.00413.x

[54] Kobayashi, N., Saito, T., Uematsu, T., Kishi, K., Toba, M., Kohda, N. and Suzuki, T. (2011) Oral Administration of Heat-Killed Lactobacillus pentosus Strain b240 Augments Protection against Influenza Virus Infection in Mice. International Immunopharmacology, 11, 199-203. http://dx.doi.org/10.1016/j.intimp.2010.11.019

[55] Corcoran, B.M., Ross, R.P., Fitzgerald, G.F., Dockery, P. and Stanton, C. (2006) Enhanced Survival of GroESL-Overproducing Lactobacillus paracasei NFBC 338 under Stressful Conditions Induced by Drying. Applied and Environmental Microbiology, 72, 5104-5107. http://dx.doi.org/10.1128/AEM.02626-05

[56] Savage, D. (1977) Microbiology of the Gastrointestinal Tract. Annual Review of Microbiology, 31, 107-133. http://dx.doi.org/10.1146/annurev.mi.31.100177.000543

[57] McCraken, V.J. and Lorenz, R.G. (2001) The Gastrointestinal Ecosystem: Aprecarious Alliance among Epithelium, Immunity and Microbiota. Cellular Microbiology, 3, 1-11. http://dx.doi.org/10.1046/j.1462-5822.2001.00090.x

[58] Simon, G.L. and Gorbach, S.L. (1984) Intestinal Flora in Health and Disease. Gastroenterology, 86, 174-193.

[59] Mills, S., Stanton, C., Fitzgerald, G.F. and Ross, R.P. (2011) Enhancing the Stress Responses of Probiotics for a Lifestyle from Gut to Product and Back Again. Microbial Cell Factories, 10, S19. http://dx.doi.org/10.1186/1475-2859-10-S1-S19

[60] Dethlefsen, L., Eckburg, P.B., Bik, E.M. and Relman, D.A. (2006) Assembly of the Human Intestinal Microbiota. Trends in Ecology \& Evolution, 21, 517-523. http://dx.doi.org/10.1016/j.tree.2006.06.013

[61] Montville, T.J. and Matthews, K. (2005) Food Microbiology: An Introduction. ASM Press, Washington DC.

[62] Arvola, T., Laiho, K., Torkkeli, S., Mykkanen, H., Salminen, S., Maunula, L. and Isolauri, E. (1999) Prophylactic Lactobacillus GG Reduces Antibiotic-Associated Diarrhea in Children with Respiratory Infections: A Randomized Study. Pediatrics, 104, e64. http://dx.doi.org/10.1542/peds.104.5.e64

[63] Turcanu, V. and Lack, G. (2006) Molecular and Immunological Responses to Food. In: Maleki, S.J., Burks, A.W. and Helm, R.M., Eds., Food Allergy, ASM Press, Washington DC, 83-121.

[64] Ebel, B., Lemetais, G., Beney, L., Cachon, R., Sokol, H., Langella, P. and Gervais, P. (2014) Impact of Probiotics on 
Risk Factors for Cardiovascular Diseases. A Review. Critical Reviews in Food Science and Nutrition, 54, 175-189. http://dox.doi.org/10.1080/10408398.2011.57931

[65] Ishikawa, H., Akedo, I., Umesaki, Y., Tanaka, R., Imaoka, A. and Otani, T. (2003) Randomized Controlled Trial of the Effect of Bifidobacteria-Fermented Milk on Ulcerative Colitis. Journal of the American College of Nutrition, 22, 56-63. http://dx.doi.org/10.1080/07315724.2003.10719276

[66] Kruis, W., Fric, P., Pokrotnieks, J., Lukas, M., Fixa, B., Kascak, M., Kamm, M.A., Weismuller, J., Beglinger, C., Stolte, M., Wolff, C. and Schulze, J. (2004) Maintaining Remission of Ulcerative Colitis with the Probiotic Escherichia coli Nissle 1917 Is as Effective as with Standard Mesalazine. Gut, 53, 1617-1623. http://dx.doi.org/10.1136/gut.2003.037747

[67] McFarland, L.V., Surawicz, C.M., Greenberg, R.N., Fekety, R., Elmer, G.W., Moyer, K.A., Melcher, S.A., Bowen, K.E., Cox, J.L., Noorani, Z., Harrington, G., Rubin, M. and Greenwald, D. (1994) A Randomized Placebo-Controlled Trial of Saccharomyces boulardii in Combination with Standard Antibiotics for Clostridium difficile Disease. JAMA, 271, 1913-1918. http://dx.doi.org/10.1001/jama.1994.03510480037031

[68] Nista, E.C., Candelli, M., Cremonini, F., Cazzato, I.A., Zocco, M.A., Franceschi, F., Cammarota, G., Gasbarrini, G. and Gasbarrini, A. (2004) Bacillus clausii Therapy to Reduce Side-Effects of Anti-Helicobacter pylori Treatment: Randomized, Double-Blind, Placebo Controlled Trial. Alimentary Pharmacology \& Therapeutics, 20, 1181-1188. http://dx.doi.org/10.1111/j.1365-2036.2004.02274.x

[69] Wang, Y.W. and Jones, P.J.H. (2004) Conjugated Linoleic Acid and Obesity Control: Efficacy and Mechanisms. International Journal of Obesity and Related Metabolic Disorders, 28, 941-955. http://dx.doi.org/10.1038/sj.ijo.0802641

[70] Szajewska, H., Ruszczyn'ski, M. and Radzikowski, A. (2006) Probiotics in the Prevention of Antibiotic-Associated Diarrhea in Children: A Meta-Analysis of Randomized Controlled Trials. Journal of Pediatrics, 149, 367-372. http://dx.doi.org/10.1016/j.jpeds.2006.04.053

[71] de Vrese, M., Stegelmann, A., Richter, B., Fenselau, S., Laue, C. and Schrezenmeir, J. (2001) Probiotics—Compensation for Lactase Insufficiency. American Journal of Clinical Nutrition, 73, 421S-429S.

[72] Lucas, A. and Cole, T.J. (1990) Breast Milk and Neonatal Necrotising Enterocolitis. The Lancet, 336, 1519-1523. http://dx.doi.org/10.1016/0140-6736(90)93304-8

[73] Gewolb, I.H., Schwalbe, R.S., Taciak, V.L., Harrison, T.S. and Panigrahi, P. (1999) Stool Microflora in Extremely Low Birthweight Infants. Archives of Disease in Childhood Fetal Neonatal, 80, F167-F173. http://dx.doi.org/10.1136/fn.80.3.F167

[74] Reid, G., Jass, J., Sebulsky, M.T. and McCormick, J.K. (2003) Potential Uses of Probiotics in Clinical Practice. Clinical Microbiology Reviews, 16, 658-672. http://dx.doi.org/10.1128/CMR.16.4.658-672.2003

[75] Hoyos, A.B. (1999) Reduced Incidence of Necrotizing Enterocolitis Associated with Enteral Administration of Lactobacillus acidophilus and Bifidobacterium infantis to Neonates in an Intensive Care Unit. International Journal of Infectious Diseases, 3, 197-202. http://dx.doi.org/10.1016/S1201-9712(99)90024-3

[76] Caplan, M.S. and Jilling, T. (2000) Neonatal Necrotizing Enterocolitis: Possible Role of Probiotic Supplementation. Journal of Pediatric Gastroenterology and Nutrition, 30, S18-S22. http://dx.doi.org/10.1097/00005176-200000002-00004

[77] Rohan, T. and Wainwright, L. (2014) Does Administering Probiotic Treatment to Infants under 1500 g Decrease the Incidence of Necrotising Enterocolitis? A Systematic Literature Review. Journal of Neonatal Nursing, 20, 37-42. http://dx.doi.org/10.1016/j.jnn.2013.04.007

[78] Korterink, J.J., Ockeloen, L., Benninga, M.A., Tabbers, M.M., Hilbink, M. and Deckers-Kocken, J.M. (2014) Probiotics for Childhood Functional Gastrointestinal Disorders: A Systematic Review and Meta-Analysis. Acta Paediatrica, 103, 365-372. http://dx.doi.org/10.1111/apa.12513

[79] de Silva, D., Geromi, M., Halken, S., Host, A., Panesar, S.S., Muraro, A., Werfel, T., Hoffmann-Sommergruber, K., Roberts, G., Cardona, V., Dubois, A.E.J., Poulsen, L.K., Van Ree, R., Vlieg-Boerstra, B., Agache, I., Grimshaw, K., O’Mahony, L., Venter, C., Arshad, S.H. and Sheikh, A., on Behalf of the EAACI Food Allergy and Anaphylaxis Guidelines Group (2014) Primary Prevention of Food Allergy in Children and Adults: Systematic Review. Allergy, 69, 581-589. http://dx.doi.org/10.1111/all.12334

[80] Redman, M.G., Ward, E.J. and Phillips, R.S. (2014) The Efficacy and Safety of Probiotics in People with Cancer: A Systematic Review. Annals of Oncology, 1-11. http://dx.doi.org/10.1093/annonc/mdu106

[81] Kunz, A.N., Noel, J.M. and Fairchok, M.P. (2004) Two Cases of Lactobacillus Bacteremia during Probiotic Treatment of Short Gut Syndrome. Journal of Pediatric Gastroenterology and Nutrition, 38, 457-458. http://dx.doi.org/10.1097/00005176-200404000-00017

[82] Land, M.H., Rouster-Stevens, K., Woods, C.R., Cannon, M.L., Cnota, J. and Shetty, A.K. (2005) Lactobacillus Sepsis 
Associated with Probiotic Therapy. Pediatrics, 115, 178-181. http://dox.doi.org/10.1542/peds.2004-2137

[83] National Cancer Institute (2010) Common Terminology Criteria for Adverse Events, Version 4.0. http://evs.nci.nih.gov/ftp1/CTCAE/CTCAE_4.03_2010-06-14_QuickReference_8.5x11.pdf

[84] Bermúdez-Humarán, L.G., Kharrat, P., Chatel, J.-M. and Langella, P. (2011) Lactococci and Lactobacilli as Mucosal Delivery Vectors for Therapeutic Proteins and DNA Vaccines. Microbial Cell Factories, 10, S4. http://dx.doi.org/10.1186/1475-2859-10-S1-S4

[85] Davis, C. (2014) Enumeration of Probiotic Strains: Review of Culture-Dependent and Alternative Techniques to Quantify Viable Bacteria. Journal of Microbiological Methods, 103, 9-17. http://dx.doi.org/10.1016/j.mimet.2014.04.012

[86] Brooker, B.E. (1995) Imaging Food Systems by Confocal Scanning Laser Microscopy. In: Dickinson, E., Ed., New Physico-Chemical Techniques for the Characterization of Complex Food Systems, Blackie Academic and Profession, London, 43-68.

[87] Heertje, I., van der Vlist, P., Blonk, J.C.G., Hendrickx, H.A.C. and Brackenhof, G.J. (1987) Confocal Scanning Laser Microscopy in Food Research: Some Observations. Food Microstructure, 6, 115-120.

[88] Auty, M.A.E., Gardinere, G.C., Mc Breaty, S.J., O’Sullivan, E.O., Muerill, D.M., Collins, J.K., Fitzgerald, G.J., Stanton, C. and Ross, R.P. (2001) Direct in Situ Viability Assessment of Bacteria in Probiotic Dairy Products Using Viability Staining in Conjunction with Confocal Scanning Laser Microscopy. Applied and Environmental Microbiology, 67, 420-425.

[89] Villlarreal, M.L.M., Padiha, M., Vieira, A.D.S., de Melo Franco, B.D.G., Martinez, R.C.R. and Saad, S.M.I. (2013) Advantageous Direct Quantification of Viable Closely Related Probiotics in Petit-Suisse Cheeses under in Vitro Gastrointestinal Conditions by Propidium Monoazide-qPCR. PLoS ONE, 8, e82102. http://dx.doi.org/10.1371/journal.pone.0082102

[90] Nogva, H.K., Drømtorp, S.M., Nissen, H. and Rudi, K. (2003) Ethidium Monoazide for DNA-Based Differentiation of Viable and Dead Bacteria by 5'-Nuclease PCR. BioTechniques, 34, 804-808, 810, 812-813.

[91] Fittipaldi, M., Nocker, A. and Codony, F. (2012) Progress in Understanding Preferential Detection of Live Cells Using Viability Dyes in Combination with DNA Amplification. Journal of Microbiolgical Methods, 91, 276-289.

[92] Chen, S., Cao, Y., Ferguson, L.R., Shu, Q. and Garg, S. (2012) Flow Cytometric Assessment of the Protectants for Enhanced in Vitro Survival of Probiotic Lactic Acid Bacteria through Simulated Human Gastro-Intestinal Stresses. Applied Microbiology and Biotechnology, 95, 345-356.

[93] FAO/WHO (2002) Joint FAO/WHO Working Group Report on Drafting Guidelines for the Evaluation of Probiotics in Food. London, Ontario, Canada, April 30 and May 1.

http://www.who.int/foodsafety/publications/fs management/probiotics2/en/

[94] Tenover, F.C. (2006) Mechanisms of Antimicrobial Resistance in Bacteria. American Journal of Medicine, 119, S3S10. http://dx.doi.org/10.1016/j.amjmed.2006.03.011

[95] D’Aimmo, M.R., Modesto, M. and Biavati, B. (2007) Antibiotic Resistance of Lactic Acid Bacteria and Bifidobacterium Spp. Isolated from Dairy and Pharmaceutical Products. International Journal of Food Microbiology, 115, 35-42. http://dx.doi.org/10.1016/j.ijfoodmicro.2006.10.003

[96] Fukao, M. and Yajima, N. (2012) Assessment of Antibiotic Resistance in Probiotic Lactobacilli. In: Pana, M., Ed., Antibiotic Resistant Bacteria-A Continuous Challenge in the New Millekium, InTech. http://cdn.intechopen.com/pdfs/34707.pdf

[97] Patel, A.R., Shah, N.P. and Prajapati, J.B. (2012) Antibiotic Resistance Profile of Lactic Acid Bacteria and Their Implication in Food Chain. World Journal of Dairy \& Food Sciences, 7, 202-211. http://dx.doi.org/10.5829/idosi.wjdfs.2012.7.2.1113

[98] Flórez, A.B., Danielsen, M., Korhonen, J., Zyckal, J., von Wright, A., Bardowski, J. and Mayo, B. (2007) Antibiotic Survey of Lactococcus lactis Strains to Six Antibiotics by Etest and Establishment of New Susceptibility-Resistance Cut-Off Values. Journal of Dairy Research, 74, 262-268. http://dx.doi.org/10.1017/S0022029907002543

[99] Ammor, M.S., Flórez, A.B., van Hoek, A.H., de Los Reyes-Gavilán, C.G., Aarts, H.J., Margolles, A. and Mayo, B. (2008) Molecular Characterization of Intrinsic and Acquired Antibiotic Resistance in Lactic Acid Bacteria and Bifidobacteria. Journal of Molecular Microbiology and Biotechnology, 14, 6-15. http://dx.doi.org/10.1159/000106077

[100] Klare, I., Konstabel, C., Werner, G., Huys, G., Vankerckhoven, V., Kahlmeter, G., Hildebrandt, B., Müller-Bertling, S., Witte, W. and Goossens, H. (2007) Antimicrobial Susceptibilities of Lactobacillus, Pedioccoccus and Lactococcus Human Isolates and Cultures Intended for Probiotic or Nutritional Use. Journal of Antimicrobial Chemotherapy, 59, 900-912. http://dx.doi.org/10.1093/jac/dkm035

[101] Korhonen, J.M., Van Hoek, A.H., Saarela, M., Huys, G., Tosi, L., Mayrhofer, S. and Wright, A.V. (2010) Antimicrobial Susceptibility of Lactobacillus rhamnosus. Beneficial Microbes, 1, 75-80.

http://dx.doi.org/10.3920/BM2009.0002 
[102] Salminen, S., Ouwenhand, A., Benno, Y. and Lee, Y.K. (1999) Probiotics: How Should They Be Defined? Trends in Food Science and Technology, 10, 107-110. http://dx.doi.org/10.1016/S0924-2244(99)00027-8

[103] Chikindas, M.L. (2014) Probiotics and Antimicrobial Peptides: The Creatures’ and Substances’ Future in the TwentyFirst Century: An Opinion Letter. Probiotics and Antimicrobial Proteins, 6, 69-72. http://dx.doi.org/10.1007/s12602-014-9161-7

[104] Besselink, M.G., van Santvoort, H.C., Buskens, E., Boermeester, M.A., van Goor, H., Timmerman, H.M., Nieuwenhuijs, V.B., Bollen, T.L., van Ramshorst, B., Witterman, B.J.M., Rosman, C., Ploeg, R.J., Brink, M.A., Schaapherder, A.F.M., Dejong, C.H.C., Wahab, P.J., van Laarhoven, C.J.H.M., van der Harst, E., van Eijck, C.H.J., Cuesta, M.A., Akkermans, L.M.A. and Gooszen, H.G. (2008) Probiotic Prophylaxis in Predicted Severe Acute Pancreatitis: A Randomised, Double-Blind, Placebo-Controlled Trial. The Lancet, 371, 651-659. http://dx.doi.org/10.1016/S0140-6736(08)60207-x 
Scientific Research Publishing (SCIRP) is one of the largest Open Access journal publishers. It is currently publishing more than 200 open access, online, peer-reviewed journals covering a wide range of academic disciplines. SCIRP serves the worldwide academic communities and contributes to the progress and application of science with its publication.

Other selected journals from SCIRP are listed as below. Submit your manuscript to us via either submit@scirp.org or Online Submission Portal.
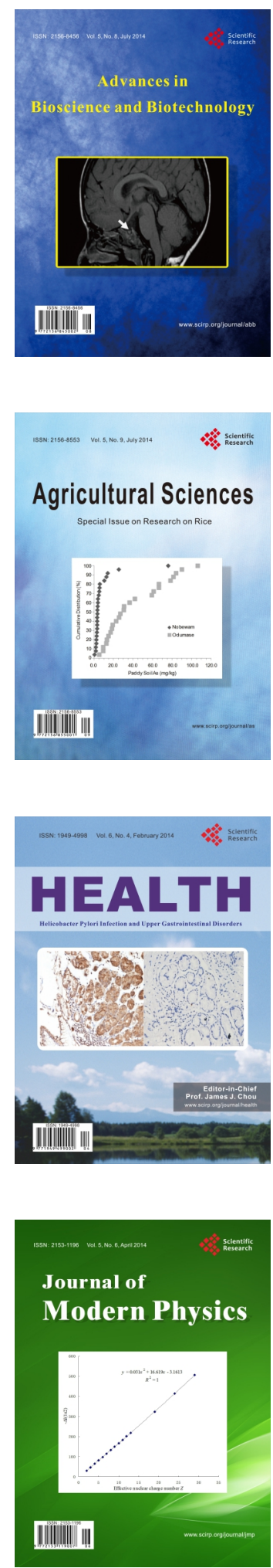
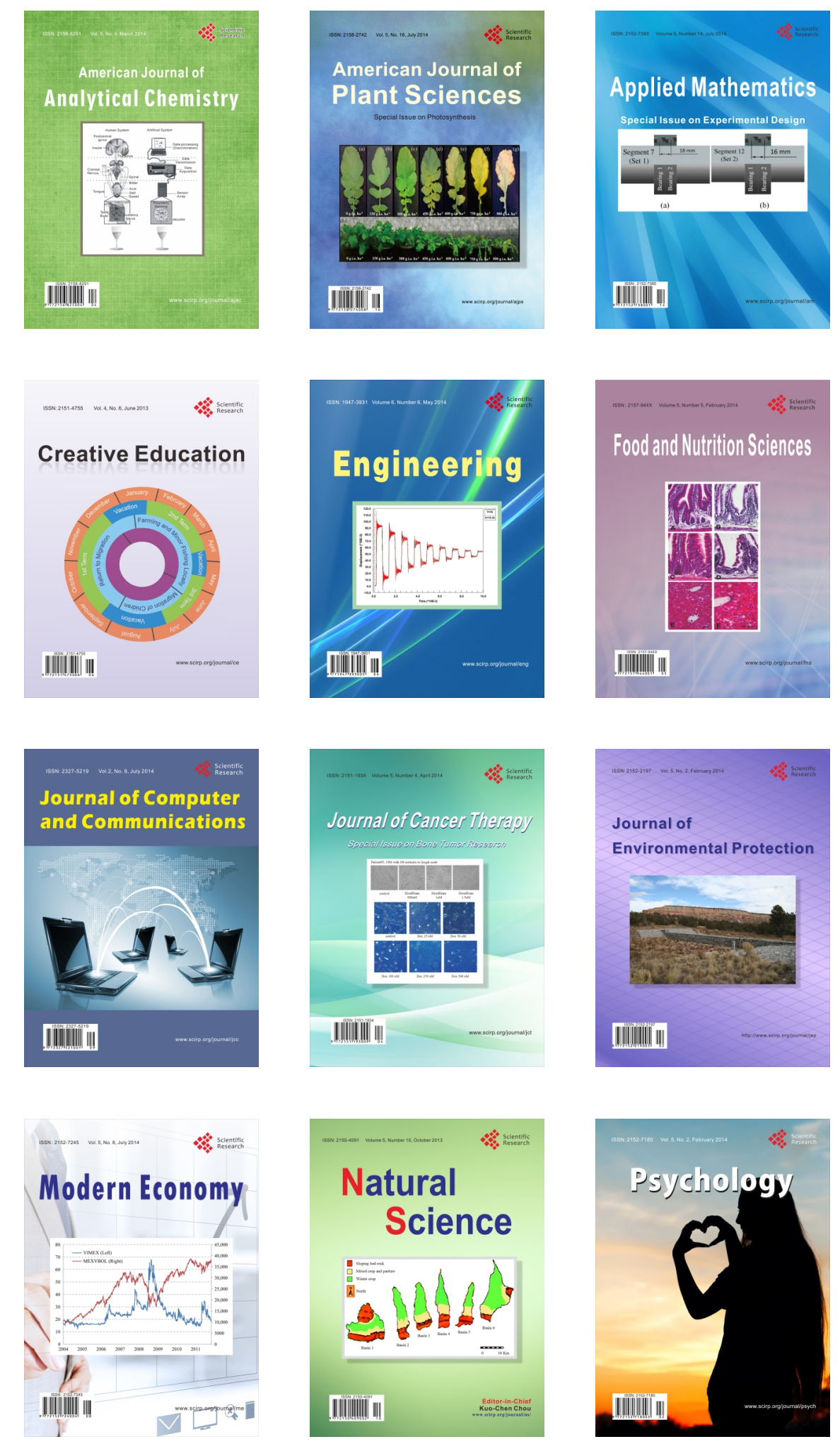